Jhon D. Pasalbessy, Dampak Tindak Kekerasan.................... Jurnal Sasi Vol.16. No.3 Bulan Juli - September 2010

\title{
DAMPAK TINDAK KEKERASAN \\ TERHADAP PEREMPUAN DAN ANAK SERTA SOLUSINYA
}

\author{
Oleh : John Dirk Pasalbessy
}

\begin{abstract}
iolence is not just an individual problem or a national problem, but is already a global problem, even transnational. In the context of protection of human rights, as human beings, women and children also have the same rights. Efforts to prevent or cope with a variety of behaviors and violence experienced by women and children already have received serious attention and treatment. Therefore, the approach in handling these issues must be integrated (integrated), where in addition to the legal approach should also consider non-legal approach which is precisely the cause of violence.
\end{abstract}

Key words: Violence

\section{A. LATAR BELAKANG.}

Sukacita yang sesungguhnya bagi manusia adalah saling berperilaku ramah kepada sesama, sehingga masing-masing mendapatkan kemurahan hati (Marcus Aurelius)

Pesan di atas menarik untuk dirujuk dalam perbincangan tentang tindak kekerasan terhadap perempuan dan anak. Betapa tidak, karena saat ini kekerasan merupakan manifestasi perilaku emosional manusia, ketimbang perilaku rasionalnya. Ini beralasan, karena di mana-mana banyak dihadapi berbagai kasus tindak kekerasan yang korbannya adalah perempuan dan anak-anak. Persoalannya sejauhmana kita semua ikut merasa bertanggungjawab untuk mencari solusi pemecahan masalah ini.

Dari topik di atas, ada beberapa hal yang dapat dipercakapkan, yakni (a) apa itu kekerasan; (b) kenapa korban kekerasan itu cenderung dialami oleh kelompok yang rentang, seperti perempuan dan anak; dan (c) bagaimana solusinya. Ketiga hal ini patut mendapat perhatian, karena selama ini dilihat dari segi etika, moral maupun hukum, semua orang pasti tahu bahwa tindak kekerasan merupakan suatu perilaku manusia yang tidak pantas dilakukan. Menariknya, diantara mereka yang tahu tentang kekerasan itu, ada diantaranya yang justru sengaja dan pernah melakukannya, bahkan korban yang timbul terkesan dibiarkan, entah itu disengajakan atau memang merupakan sebuah fenomena kemanusiaan di abad ini.

\section{B. PEMBAHASAN}

Menarik dari topik ini adalah, bahwa ternyata tindak kekerasan tidak hanya merupakan masalah individual atau masalah nasional saja, tetapi sudah merupakan masalah global, bahkan transnasional. Karena itu di dalam masyarakat dikenal berbagai istilah, seperti "violence against women, "gender based violence", "gender violence", "domestic violence" yang korbannya adalah peremuan, sementara bagi anak-anak dikenal juga istilah, "working children", "street childern", "childern in 
armed conflict", "urban war zones", dan sebagainya.

Dalam konteks perlindungan HAM, sebagai manusia, perempuan dan anak juga memiliki hak yang sama dengan manusia lainnya dimuka bumi ini, yakni hak yang dipahami sebagai hak-hak yang melekat (inherent) secara alamiah sejak ia dilahirkan, dan tanpa itu manusia (perempuan dan anak) tidak dapat hidup sebagai manusia secara wajar.

Atas pengakuan ini, tampak pelbagai pernyataan bahwa kekerasan terhadap perempuan dan anak merupakan rintangan terhadap keberhasilan pembangunan. Bagaimanapun juga tindak kekerasan akan berdampak pada kurangnya rasa percaya diri, menghambat kemampuan perempuan untuk berpartisipasi dalam kegiatan sosial, mengganggu kesehatannya, mengurangi otonomi, baik di bidang ekonomi, politik, sosial budaya serta fisik. Demikian juga dengan anak, kepercayaan pada diri sendiri dalam pertumbuhan jiwanya akan terganggu dan dapat menghambat proses perkembangan jiwa dan masa depannya. Padahal Undang-Undang No. 23 Tahun 2002 Tentang Perlindungan Anak memberikan kewajiban bagi semua pihak termasuk negara untuk melindunginya.

\section{Apa itu kekerasan?}

Kekerasan merupakan sebuah terminologi yang sarat dengan arti dan makna "derita", baik dikaji dari perspektif psikologik maupun hukum, bahwa di dalamnya terkandung perilaku manusia (seseorang/kelompok orang) yang dapat menimbulkan penderitaan bagi orang lain, (pribadi/ kelompok).

Tindak kekerasan atau "violence" oleh Jerome Skolncik didefinsikan sebagai “... an ambiguous term whose meaning is established throught political process". Dalam arti tingkah laku, Michael Levi lalu menyebutkan kekerasan sebagai ".. its content and cuase are socially constructed".

Dari pandangan demikian, tampaknya perumusan tindak kekerasan sangat terkait dengan tingkah laku manusia yang bersifat kejam dan tidak manusiawi, namun tidak jelas apakah perumusan itu juga menampung aspirasi kaum minoritas (perempuan dan anak) yang selama ini rentang terhadap kekerasan.

Pada tahun 1993 Sidang Umum PBB mengadopsi deklarasi yang menentang kekerasan terhadap perempuan yang telah dirumuskan tahun 1992 oleh Komisi Status Perempuan PBB, di mana dalam pasal 1 disebutkan bahwa, "kekerasan terhadap perempuan mencakup setiap perbuatan kekerasan atas dasar perbedaan kelamin, yang mengakibatkan atau dapat mengakibatkan kerugian atau penderitaan terhadap perempuan baik fisik, seksual maupun psikhis, termasuk ancaman perbuatan tersebut, paksaan dan perampasan kemerdekaan secara sewenangwenang, baik yang terjadi dalam kehidupan yang bersifat publik maupun privat".

Bahkan secara jelas pengertian kekerasan ini kemudian dapat dilihat di dalam Konvensi Tentang Penyiksaan dan Perilaku Kejam, Tak berperikemanusiaan dan Merendahkan, yang diratifikasi pada bulan Nopember 1998, disebutkan bahwa, “... Torture ... means any act by which severe pain or suffering whether physical or mental, is intentionally inflicted on a person ...". Demikian juga di dalam laporan Wolrd Conference (1995) di Beijing, pada butir 113 dirumuskan bahwa kekerasan terhadap perempuan sebagai "setiap tindakan berdasarkan gender yang menyebabkan atau dapat menyebabkan kerugian atau penderitaan fisik, seksual atau psikoloogis terhadap perempuan, termasuk ancaman untuk melakukan tindakan tersebut, pemaksaan atau perampasan kemerdekaan, baik yang terjadi dalam kehidupan masyarakat atau pribadi".

Dalam kaitannya dengan penggunaan hukum (pidana), jika terjadi tindak kekerasan terhadap perempuan dan anak, maka terminologinya tidak boleh samar. Ini dimaksudkan agar tidak timbul "multiintepretasi" yang pada gilirannya dapat menimbulkan kesulitan baik pada masyarakat maupun penegak hukum. 
KUHP Indonesia misalnya, hanya merumuskan kekerasan sebagai perbuatan membuat orang pingsan atau tidak berdaya (pasal 89). Jelaslah bahwa perumusan ini membatasi perilaku kekerasan pada perilaku fisik belaka, padahal bila dilihat dari kenyataan di dalam masyarakat tindak kekerasan dapat meliputi pula : (a) fisik; (b) seksual; (c) psikologis; (d) politis; dan (e) ekonomi. Selanjutnya KUHP merumuskan beberapa tingkah laku kekerasasn yang korbannya adalah perempuan dan anak, seperti : (a) pornografi (Pasal 282 dst); (b) perkosaan (Pasal 285 dst); (c) perbuatan cabul (Pasal 290 dst); (d) perdagangan wanita (Pasal 297); (e) penculikan (Pasal 328); (f) penganiayaan (Pasal 351 dst); (g) pembunuhan (Pasal 338) dan; (h) perampokan (Pasal 363).

Perilaku kekerasan di atas sebahagian besar merupakan kekerasan fisik, kecuali pornografi, di mana ancaman pidananya berkisar antara 1 tahun pidana penjara hingga pidana mati. Dari sekian banyak ketentuan tentang kekerasan, hanya sedikit saja yang menyebutkan jenis kelamin korban perempuan. Pasal yang secara eksplisit menyebutkannya antara lain, Pasal 285 KUHP tentang perkosaan dan Pasal 297 KUHP tentang perdagangan perempuan.

Sama halnya dengan tindak kekerasan terhadap perempuan, perilaku kekerasan sebagaimana dikemukakan di atas juga memiliki pengertian yang sama dengan anak, karena pengertian tersebut bersifat multidimensi, mulai dari yang bersifat struktural dan sistematik hingga kekerasan karena perang, perselisihan komunal, perpecahan keluarga dan kekerasan interpersonal. Tindak kekerasan mana secara hakiki berakar pada apa yang dinamakan penyalahgunaan, penelantaraan dan eksploitasi anak, di mana pelakunya bisa saja negara, sektor swasta, personal petugas hukum, keluarga atau perorangan.

\section{Perempuan dan Anak Sebagai Korban Tindak Kekerasan}

Kekerasan yang telah, sementara bahkan mungkin akan dialami oleh bangsa
Indonesia selama ini merupakan masalah sosial dan kemanusiaan yang pelu mendapat perhatian. Di mana-nama kini berjatuhan korban tindak kekerasan yang umumnya kalangan perempuan dan anak-anak.

Fenomena ini mengingatkan kita pada jaman jahilliah yang berlandaskan hukum rimba atau jaman Herodes yang membenarkan hukum penguasa, serta jaman-jaman lainnya yang dikenal dengan jaman kegelapan. Pertanyaannya, apakah telah terjadi kemunduran moral dan nilai dalam masyarakat kita yang katanya menyukai harmoni dan membenci konflik, apalagi kekerasan. Perempuan dan anak sebagai korban tindak kekerasan bukan merupakan fenomena baru, kitab sejarah mengungkapkan praktek-praktek masa lalu yang mengorbankan perempuan, baik dewasa (pengorban depan altar) maupun korban anak-anak (pembunuhan bayi berjenis kelamin perempuan).

Cerita tentang korban tindak kekerasan dikalangan perempuan dan anak memang sedikit sekali ditemukan di dalam berbagai literatur yang ada, karena itu jarang terungkap bahwa viktimisasi terhadap perempuan melalui tindak kekerasan diajukan ke peradilan pidana. Masalahnya mungkin pada persepsi masyarakat, baik secara keseluruhan maupun kaum perempuan itu sendiri, bahwa kekerasan yang dialaminya adalah lebih baik untuk disembunyikan saja. Ini tentu ada kaitannya dengan nilai-nilai yang berkembang dalam masyarrakat mengenai kedudukan perempuan selama ini dalam masyarakat. Kalangan perempuan terkadang menyembunyikan viktimisasi terhadap dirinya karena berbagai alasan, namun yang utama adalah karena mereka tidak ingin dirinya diketahui orang lain atau mungkin akan mencoreng harga sendiri, terlepas dari ada tidaknya konstribusi perempuan terhadap tindak kekerasan yang dialaminya.

Sebagai akibat persepsi (mungkin juga mispersepsi) semacam ini, media massa juga terkadang juga terkadang melakukan hal yang sama, sehingga terjadi apa yang disebut dengan "selctive inattention", yakni 
memilih berita tertentu untuk dijadikan informasi bagi konsumsi masyarakat. Ekspose semacam ini setidaknya melahirkan proses viktimisasi terhadap perempuan dan anak yang pada umumnya difokuskan pada : (a) tindak kekerasan seksual; (b) tindak kekerasan yang menimbulkan luka berat; dan (c) tindak kekerasan yang mengakibatkan kematian.

Sering juga muncul persepsi bahwa seorang perempuan yang menjadi korban akan berpikir bahwa ia mempunyai andil terhadap suatu kejahatan, walaupun sebenarnya tidak demikian. Contohnya perkosaan, seorang perempuan korban perkosaan cenderung untuk menyimpan dukanya (psikis dan fisik), karena mungkin ia menganggap bahwa kedatangannya ke lembaga penegak hukum hanya akan menimbulkan viktimisasi ganda pada dirinya.

Berbagai tindak kekerasan yang sering terjadi dan menimbulkan korban dikalangan perempuan seperti, (a) serangan seksual; (b) kasus pembunuhan terhadap ibu atau nenek baik karena motif ekonomi maupun karena rasa marah yang tidak terkendali; (c) pornografi; (d) tindak kekerasan oleh majikan terhadap pembantu rumah tangga yang sering terjadi dan umumnya dilandasi oleh rasa jengkel bahkan benci, serta beberapa tindak kekerasan lainnya.

Demikian juga korban tindak kekerasan terhadap anak dalam kasus seksual, di mana posisi anak sering dianggap sebagai derivat dari orang tua yang sering membuatnya tidak berdaya. Contohnya, perilaku "incest" yang mengakibatkan sang anak terpaksa melahirkan bayi yang merupakan hasil hubungan "insestuos" dengan ayah kandungnya sendiri. Di samping itu, dikenal beberapa kasus yang berkaitan dengan eksploitasi, penganiayaan dan pembunuhan terhadap anak oleh orang tuanya.

Secara garis besar, anak yang mengalami tindak kekerasan dapat terjadi karena : (a) Working Children, di mana banyak anak-anak yang menjadi pekerja penuh, (full time child labour) perdagangan anak (sale fo children), prostitusi anak (child prostitution), perbudakan anak (child bondage), ponografi anak (child pornography) akibat meningkatnya "sex tourism"'; (b) Street Childern, di mana diperkirakan terdapat sekitar kurang lebih 100 hingga 150 juta anak jalanan diseluruh dunia saat ini. Yang memprihatinkan adalah, bahwa di samping mereka berjuang untuk mempertahankan hidup secara materiil, juga menjadi sasaran penyalahgunaan dan eksploitasi, seperti street theieves, street prostitution, drug trade, dan aktivitas kejahatan terorganiser lainnya; (c) Childern in Armed Conflict, di mana dalam sutiasi konflik, banyak anak-anak yang menjadi korban, seperti terbunuh, cacat, mengungsi bahkan ada yang hilang. Belum lagi yang menjadi korban perkosaan dan menderita tekanan kejiwaan (stress dan trauma).

Permasalahan yang sulit dihadapi adalah bagaimana melakukan pembinaan dan reorientasi mereka dari situasi/budaya konflik ke budaya damai (culture of peace); (d) Urban war zones, di mana suasana kekerasaan dan ketidak-terntraman dalam lingkungan kehidupan sehari-hari baik di kota maupun pada wilayah "zona peperangan” yang menempatkan anak-anak dalam resiko yang sangat gawat (grave risk), terutama jika timbul kemelaratan, penggunaan obat bius dan senjata serta kejahatan sebagai kenyataan hidup seharihari.

Yang menarik untuk diperbincangkan selanjutnya adalah, apakah tindak kekerasan terhadap perempuan dan anak ini merupakan imbas dari kekacauan norma (anomie) yang kini telah dialami oleh berbagai komunitas di Indonesia. Ini butuh penelitian yang akurat untuk menjawabnyaa secara akademik.

\section{Solusi Pemcehannya}

Tampaknya tindak kekerasan terhadap perempuan dan anak merupakan masalah interdispliner, baik politis, sosial, budaya, ekonomis maupun aspek lainnya. Diakui 
bahwa tindak kekerasan akan banyak terjadi, di mana ada kesengjangan ekonomis antara laki-laki dan perempuan, penyelesaian konflik dengan kekerasan, dominasi lakilaki dan ekonomi keluarga serta pengambilan keputusan yang berbasis pada laki-laki. Sebaliknya, jika perempuan memiliki kekuasaan diluar rumah, maka intervensi masyarakat secara aktif disamping perlindungan dan kontrol sosial yang kuat memungkinan perempuan dan anak menjadi korban kekerasan semakin kecil.

Dari berbagai pengalaman selama ini, maka solusi terhadap penanggulangan tindak kekerasan terhadap perempuan mesti mencakup hal-hal sebagai berikut :

1. Meningkatkan kesadaran perempuan akan hak dan kewajibannya di dalam hukum melalui latihan dan penyuluhan (legal training).

2. Meningkatkan kesadaran masyarakat betapa pentingnya usaha untuk mengatasi terjadinya kekerasan terhadap perempuan dan ana, baik di dalam konteks individual, sosial maupun institusional;

3. Meningkatkan kesadaran penegak hukum agar bertindak cepat dalam mengatasi kekerasan terhadap perempuan maupun anak;

4. Bantuan dan konseling terhadap korban kekerasan terhadap perempuan dan anak;

5. Melakukan kampanye anti kekerasan terhadap perempuan dan anak yang dilakukan secara sistematis dan didukung oleh karingan yang mantap.

6. Pembaharuan hukum teristimewa perlindungan korban tindak kekerasan yang dialami oleh perempuan dan anakanak serta kelompok yang rentang atas pelanggaran HAM.

7. Pembaharuan sistem pelayanan kesehatan yang kondusif guna menanggulangi kekerasan terhadap perempuan dan anak;

8. Bagi anak-anak diperlukan perlindungan baik sosial, ekonomi mauoun hukum bukan saja dari orang tua, tetapi semua pihak, termasuk masyarakat dan negara.
9. Membentuk lembaga penyantum korban tindak kekerasan dengan target khusus kaum perempuan dan anak untuk diberikan secara cuma-cuma dalam bentuk konsultasi, perawatan medis maupun psikologis

10. Meminta media massa (cetak dan elektronik) untuk lebih memperhatikan masalah tindak kekerasan terhadap perempuan dan anak dalam pemberitaannya, termasuk memberi pendidikan pada publik tentang hak-hak asasi perempuan dan anak-anak.

\section{P E N U T U P}

Upaya untuk mencegah dan atau menanggulangi berbagai perilaku kekerasan yang dialami perempuan dan anak sudah mesti mendapat perhatian dan penanganan yang serius. Oleh sebab itu, pendekatan dalam penanganan masalah ini mesti bersifat terpadu (integrated), di mana selain pendekatan hukum juga harus mempertimbangkan pendekatan non hukum yang justru merupakan penyebab terjadinya kekerasan. Dengan cara meningkatkan kesadaran perempuan akan hak dan kewajibannya di dalam hukum, meningkatkan kesadaran masyarakat betapa pentingnya usaha untuk mengatasi terjadinya kekerasan terhadap perempuan dan anak, meningkatkan kesadaran penegak hukum agar bertindak cepat dalam mengatasi kekerasan terhadap perempuan maupun anak, memberikan bantuan dan konseling terhadap korban kekerasan terhadap perempuan dan anak, melakukan pembaharuan sistem pelayanan kesehatan yang kondusif guna menanggulangi kekerasan terhadap perempuan dan anak, Bagi anak-anak diperlukan perlindungan baik sosial, ekonomi maupun hukum. Disampin itu bantuan media massa (cetak 
dan elektronik) untuk lebih memperhatikan masalah tindak kekerasan terhadap perempuan dan anak dalam pemberitaannya, termasuk memberi pendidikan publik tentang hak-hak asasi perempuan dan anakanak.

\section{DAFTAR PUSTAKA}

Adji, Oemar Seno, Hukum dan Hukum

Pidana, Erlangga, Jakartal, 1984

Ancel, Marc, Social Defence a, modern approach to crminal problem, Routledge \& Paul Kegan, London.

Arief, Barda Nawawi, Kebijakan Legislatif Dalam Penanggulangan

Kejahatan Dengan Pidana Penjara, Ananta, Semarang, 1994

------------, Bunga Rampai Kebijakan Hukum Pidana, Citra Aditya, Bandung, 1996

Gosita, Arif, Masalah Korban Kejahatan, Akademika Presindd, Jakarta, 1983

--------------, Perlindungan Anak , Akademika Presindo, Jakarta, 1983

Hadisuprarto, Juvenille Delinquency (Pemahaman dan Penanggulangannya), UNDIP, Semarang, 1996

Pasalbessy, Tindakan Sebagai Pidana Yang Tepat Bagi Anak Yang Dipersahkan Melakukan Tindak Pidana, Skripsi, Fakultas Hukum Universitas Pattimura, 1987
Pecker, Herberth, The Limits of The Crminal Sanctions, Stanford, California, Stanford University Press, 1985

Soerjono , Sokanto, Penegakan Hukum , BPHN Depkeh, 1983

Sudarto, Kapita Selekta Hukum Pidana, Alumni, Bandung, 1981

\section{Hukum dan Hukum Pidana,}

Alumni, Bandung, 1981

-----------, Hukum Pidana dan

Perkembangan Masyarakat, Sinar Baru,

Bandung, 1983

Tappan, Paul, Juvenille Delinquency, Mc

Graw Hill Book Company, Inc, 1949

United Nations, Human Rights $A$ Compilatonof International Instruments (Volume I Second Part) Universal Instrrumens

\section{A Compilatonof International}

Instruments (Volume II Forts Part)

Universal Instrumen 